\title{
Perlindungan Hukum terhadap Lagu Daerah yang Tidak Diketahui Penciptanya
}

\author{
Berthon Jonathan \\ Fakultas Hukum Universitas Indonesia \\ Email : berthonjonathan@gmail.com
}

\begin{abstract}
This paper raises the legal issue regarding legal protection of the folk song in Indonesia. Indonesia has 34 provinces so they have their own folk songs. Some of the folk songs are not known to be creators so very vulnerable to change, play the folk song within ways that do not conform to the values that live in the native communities and even claimed by irresponsible parties. This research is normative legal research, using a statute approach, utilizing primar and secondary legal materials. Analysis of legal material is carried out using qualitative analysis, with deductive reasoning. The results showed that role of Nation is very important in the legal protection of folk songs. Unknown folk song creators are arranged in Article 38 of Copyright Law. However, there are no derivative rules such as the Government Regulations specifically regulating Article 38 number (4) of Copyright Law
\end{abstract}

Keywords : Copyright; The Folk Song; Legal Protection.

\begin{abstract}
ABSTRAK
Tulisan ini mengangkat masalah hukum tentang perlindungan hukum lagu daerah di Indonesia. Indonesia terdiri dari 34 Provinsi sehingga memiliki lagu daerahnya masingmasing. Beberapa lagu daerah daerah tidak diketahui siapa penciptanya sehingga sangat rentan untuk diubah, dibawakan ulang dengan cara yang tidak sesuai dengan nilai-nilai yang hidup di masyarakat asalnya bahkan diklaim oleh pihak yang tidak bertanggung jawab. Penelitian ini merupakan penelitian hukum normatif, dengan menggunakan pendekatan peraturan perundang-undangan, memanfaatkan bahan hukum primer dan sekunder. Analisis bahan hukum dilakukan dengan menggunakan analisis kualitatif, dengan penalaran deduktif. Hasil penelitian menunjukkan bahwa lagu daerah yang tidak diketahui Penciptanya dipegang oleh Negara sehingga peran negara sangat penting dalam perlindungan hukum lagu daerah. Lagu daerah yang tidak diketahui penciptanya diatur dalam Pasal 38 Undang-Undang Nomor 28 Tahun 2014 tentang Hak Cipta. Namun belum ada aturan turunan seperti Peraturan Pemerintah yang mengatur secara khusus mengenai pengaturan lagu daerah sebagaimana dimaksud dalam Pasal 38 ayat (4) Undang-Undang Nomor 28 Tahun 2014 tentang Hak Cipta.
\end{abstract}

Kata Kunci : Hak Cipta; Lagu Daerah; Perlindungan Hukum.

\section{Pendahuluan}

Indonesia terkenal dengan beraneka ragam suku, adat, dan bahasa daerah yang masing-masing memiliki kebudayaan yang unik dan mampu memikat wisatawan baik dalam negeri maupun mancanegara. Bahkan musisi Indonesia dapat dikenal dunia karena membawakan lagu daerah Indonesia. Grup musikTen 2 Five merilis album daerah baru yang berjudul Cinta Indonesia pada Rabu 
(3/12/2014). Album yang berisi 18 lagu daerah tersebut membawa grup ini melancong ke luar negeri.Lagu-lagu daerah ini mengantarkan mereka untuk membawakan lagu daerah di tempat-tempat yang belum pernah mereka datangi seperti Qatar, Jepang, Taiwan, dan beberapa lainnya. ${ }^{1}$

Seluruh wilayah Indonesia dari Sabang sampai dengan Merauke memiliki ciri khas budayanya masing-masing. Setiap daerah memiliki lagu daerah, tarian daerah, kerajinan-kerajinan daerah yang memikat para wisatawan dari mancanegara yang jauhjauh datang berwisata ke Indonesia karena tertarik untuk melihat secara langsung kebudayaan kita tersebut bahkan mempelajarinya secara mendalam. Hal ini menunjukan bahwa bangsa Indonesia memiliki kreativitas yang tinggi sehingga menjadi daya tarik yang hanya dapat ditemui di Indonesia. Lagu daerah, tari-tarian, kerajinan tangan berupa patung, kain tenun, pahatan kayu serta karya sastra berupa cerita rakyat tersebut merupakan sebuah ciptaan. Ciptaan dari sang pencipta itu memiliki hak atas kekayaan intelektual (selanjutnya disebut HKI).

Lagu masuk dalam ranah HKI yang dilindungi sebagaimana diatur dalam Pasal

\footnotetext{
${ }^{1}$ Achmad Rafiq, 2014 Lagu Daerah Antarkan Ten 2 Five ke Luar Negeri, https://www.tribunnews.com/seleb/2014/12/0 5/lagu-daerah-antarkan-ten-2-five-ke-luar-negeri $\begin{array}{lllll}\text { diakses } & \text { tanggal } & 14 & \text { Mei } & 2019\end{array}$
}

58 huruf (d) Undang-undang Nomor 28 Tahun 2014 tentang Hak Cipta (selanjutnya disingkat menjadi UUHC) yaitu Perlindungan Hak Cipta atas Ciptaan lagu atau musik dengan atau tanpa teks. Sebagaimana dilindungi oleh UUHC maka pencipta lagu berhak atas hak ekonomi atas hasil karya ciptaannya. Hak ekonomi ini diperlukan sebagai bentuk apresiasi atau nilai atas hasil kreatifitas dari ciptaannya yang berupa lagu yang dapat dinikmati oleh masyarakat atau orang ketika mendengarkannya. Artinya pencipta berhak atas hak ekonomi dari lagu yang dinikmati oleh masyarakat.

Namun ada juga ciptaan yang tidak diketahui siapa penciptanya. Biasanya lagulagu daerah yang sudah dinyanyikan turuntemurun dari generasi ke generasi tidak diketahui siapa sebenarnya pencipta lagu tersebut. Misalnya lagu daerah yang berjudul Butet yang berasal dari Provinsi Sumatera Utara yang hingga saat ini tidak diketahui siapa pencipta aslinya.Ada istilah orphan works atau ciptaan yang tidak diketahui pencipta yang memiliki kemiripan pengertiannya dengan ekspresi budaya tradisional yang juga tidak diketahui siapa penciptanya yang dilindungi oleh negara. Lagu daerah yang tidak diketahui penciptanya tersebut sangat rentan untuk diubah, dibawakan ulang dengan cara yang tidak sesuai dengan nilai-nilai yang hidup di masyarakat asalnya bahkan diklaim oleh 
pihak yang tidak bertanggung jawab. Hal tersebut yang kemudian akan diteliti dan dibahas lebih lanjut di dalam penulisan tulisan ini. Berdasarkan uraian di atas, diidentifikasi permasalahan yaitu Bagaimana Perlindungan hukum terhadap Ekspresi Budaya Tradisional di Indonesia? Tujuan dari tulisan ini untuk mengetahui tentang perlindungan terhadap ekspresi budaya tradisional di Indonesia.

\section{Metode Penelitian}

Jenis penelitian yang digunakan dalam tulisan ini yaitu jenis penelitian hukum normatif dan Sifat penelitian ini adalah preskriptif. Penelitian hukum dilakukan untuk memecahkan isu hukum yang diajukan. Hasil yang dicapai adalah memberikan preskripsi mengenai apa yang Pendekatan yang akan digunakan penulis dalam penelitian ini adalah pendekatan undang-undang (statute approach). Suatu penelitian normatif juga harus menggunakan pendekatan undang-undang, karena yang akan diteliti adalah berbagai aturan hukum yang menjadi fokus sekaligus tema sentral suatu penelitian. ${ }^{2}$ Jenis data yang digunakan dalam penelitian hukum normatif adalah data sekunder. Sumber bahan hukum yang digunakan penulis dalam penelitian ini antara lain: Bahan Hukum Primer, meliputi: Undang-Undang Nomor 28 Tahun 2014 tentang Hak Cipta. Bahan Hukum Sekunder,

\footnotetext{
${ }^{2}$ Johnny Ibrahim, h.302
}

meliputi: Jurnal-jurnal mengenai hak cipta , pengetahuan tradisional dan ekspresi budaya tradisonal, baik jurnal nasional maupun jurnal internasional; Karya Ilmiah hukum; Buku-buku yang berkaitan dengan penelitian hukum; Internet yang berkaitan dengan hukum kekayaan intelektual. Teknik yang dipakai dalam pengumpulan bahan hukum dalam penelitian ini adalah studi kepustakaan atau studi dokumen (library research). Teknik pengumpulan bahan hukum dimaksudkan untuk memperoleh bahanbahan hukum untuk digunakan dalam penelitian hukum adalah bersifat deduksi dengan metode silogisme. Deduksi silogisme adalah merumuskan fakta hukum dengan cara membuat kesimpulan atas premis mayor dan premis minor. Premis mayor yang dimaksud adalah aturan hukum dan premis minor adalah fakta hukum sehingga dapat ditarik kesimpulan dari kedua premis tersebut. $^{3}$

\section{Pembahasan}

Teori perlindungan hukum merupakan salah satu teori yang sangat penting untuk dikaji karena teori ini pada perlindungan hukum yang diberikan kepada masyarakat. Masyarakat yang disasarkan pada teori ini, yaitu masyarakat yang berada pada posisi yang lemah, baik secara ekonomis maupun lemah dari aspek yuridis. Istilah teori

\footnotetext{
${ }^{3}$ Peter Mahmud Marzuki, 2014, Penelitian Hukum, Jakarta: Prenandamedia Grup h. $89-90$
} 
perlindungan hukum berasal dari bahasa Inggris, yaitu legal protection theory, sedangakan dalam bahasa Belanda, disebut dengan theorie van de wettelijke bescherming, dan dalam bahasa Jerman disebut dengan theorie der rechtliche schutz. ${ }^{4}$ Pada dasarnya teori perlindungan hukum merupakan teori yang berkaitan dengan pemberian pelayanan kepada masyarakat. Roscou Pound mengemukakan hukum merupakan alat rekayasa sosial (law as tool of social engineering). Kepentingan manusia, adalah suatu tuntutan yang dilindungi dan dipenuhi manusia dalam bidang hukum. ${ }^{5}$

Menurut Satjipto Raharjo, perlindungan hukum adalah memberikan pengayoman terhadap hak asasi manusia (HAM) yang dirugikan orang lain dan perlindungan itu diberikan kepada masyarakat agar dapat menikmati semua hakhak yang diberikan oleh hukum. ${ }^{6}$ Marie Theresia Geme mengartikan perlindungan hukum adalah "berkaitan dengan tindakan negara untuk melakukan sesuatu (dengan memberlakukan hukum negara secara eksklusif) dengan tujuan untuk memberikan jaminan kepastian hak-hak seseorang atau kelompok orang. ${ }^{7}$ Teori perlindungan hukum

\footnotetext{
${ }^{4}$ Salim dan Erlies Septiana Nurbani, 2016, Penerapan Teori Hukum pada Penelitian Tesis dan Disertasi, Jakarta: Rajawali Pers, h. 259

${ }^{5}$ Ibid, h. 264

${ }^{6}$ Sajipto Raharjo, 2000, Ilmu Hukum, Bandung: PT Citra Aditya Bakti,h. 54

${ }^{7}$ Maria Theresia Geme, 2012, Perlindungan Hukum Terhadap Masyarakat Hukum Adat dalam Pengelolaan Cagar Alam Watu Ata Kabupaten
}

merupakan teori yang mengkaji dan menganalisis tentang wujud atau bentuk atau tujuan perlindungan, subjek hukum yang dilindungi serta objek perlindungan yang diberikan oleh hukum kepada subjeknya.

Unsur-unsur yang tercantum dalam definisi teori perlindungan hukum meliputi : (1) Adanya wujud atau bentuk perlindungan atau tujuan perlindungan; (2) Subjek hukum; dan (3) Objek perlindungan hukum. ${ }^{8}$ Bentuk perlindungan hukum dibagi menjadi dua bentuk, yaitu (1) Perlindungan yang bersifat preventif; Perlindungan hukum yang bersifat preventif merupakan perlindungan hukum yang sifatnya pencegahan. Perlindungan memberikan kesempatan kepada rakyat untuk mengajukan keberatan (inspraak) atas pendapatnya sebelum suatu keputusan pemerintah mendapat bentuk yang definitif. Sehingga, perlindungan hukum ini bertujuan untuk mencegah terjadinya sengketa dan sangat bersar artinya bagi tindak pemerintah yang didasarkan pada kebebasan bertindak. Dan dengan adanya perlindungan hukum yang preventif ini mendorong pemerintah untuk berhati-hati dalam mengambil keputusan yang berkaitan dengan asas freies ermessen, dan rakyat dapat mengajukan keberatan atau diminta pendapatnya mengenai rencana keputusan tersebut. ${ }^{9}$ (2) Perlindungan refresif: Perlindungan hukum

Ngada, Provinsi Nusa Tenggara Timur, Malang: Hukum Universitas Brawijaya, h. 99

${ }^{8}$ Ibid

${ }^{9}$ Ibid, h. 264 
yang refresif berfungsi untuk menyelesaikan apabila terjadi sengketa. Indonesi dewasa ini terdapat berbagai badan yang secara parsial menangani perlindungan hukum bagi rakyat, yang dikelompokan secara parsial menangani perlindungan hukum bagi rakyat, yang dikelompokan menjadi dua bagian yaitu: ${ }^{10}$ (a) Pengadilan dalam lingkup Peradilan Umum; (b) Instansi Pemerintah yang merupakan lembaga banding administrasi.

Pendaftaran hak merupakan tolak ukur perlindungan hukum. ${ }^{11}$ Untuk membuktikan pencipta memiliki hak atas hasil karya ciptanya. Pasal 64 Ayat (2) UUHC menyatakan Pencatatan Ciptaan dan Produk Hak Terkait sebagaimana dimaksud pada ayat (1) bukan merupakan syarat untuk mendapatkan Hak Cipta dan Hak Terkait. Menurut penjelasan Pasal 64 Ayat (2) UUHC tersebut bahwa Pencatatan Ciptaan dan produk Hak Terkait bukan merupakan suatu keharusan bagi Pencipta, Pemegang Hak Cipta atau Pemilik Hak Terkait. Perlindungan suatu Ciptaan dimulai sejak Ciptaan itu ada atau terwujud dan bukan karena pencatatan. Hal ini berarti suatu Ciptaan baik yang tercatat maupun tidak tercatat tetap dilindungi. Untuk memperoleh pencatatan ciptaan di Kementrian Hukum dan HAM Republik Indonesia, pemohon

\footnotetext{
${ }^{10}$ Ibid

11 Wahyu Sasongko. 2012. Indikasi Geografis Studi Tentang Kesiapan Indonesia Memberikan Perlindungan Hukum Terhadap Produk Nasional. Bandar Lampung: Universitas Lampung, h. 206.
}

dapat melakukan pengajuan permohonan melalui tiga alternatif, yaitu $:^{12}$ (a) Melalui Direktorat Jenderal Hak Kekayaan Intelektual (Ditjen HKI); (b) Melalui Kantor Wilayah Kementrian Hukum dan Hak Asasi Manusia Republik Indonesia; (c) Melalui Kuasa Hukum Konsultan HKI yang terdaftar. Seiring dengan berkembangnya teknologi dan informasi di masa sekarang ini, dunia seni yang berupa lagu, musik maupun film juga mengalami perkembangan yang signifikan. Pada gilirannya, akan melahirkan konsepsi perlindungan hukum atas kekayaan intelektual (Intellectual Property). Diaturnya ekspresi budaya tradisional pada UndangUndang Hak Cipta, maka ekspresi budaya tradisional merupakan bagian dari Hak Kekayaan Intelektual (HKI), karena budaya tersebut juga merupakan hasil dari olah pikir karya intelektual manusia, meskipun kadang tidak diketahui penemu dari budaya tersebut. Munculnya banyak sengketa dalam bidang hak kekayaan intelektual tersebut menandakan selama ini, konsep yang digunakan dalam perlindungan atas budaya lokal tersebut masih belum bisa diaplikasikan secara maksimal, atau bahkan mungkin belum ada peraturan yang bersifat teknis terhadap permasalahan yang ada tersebut khususnya yang mengatur mengenai masalah tersebut. Oleh karena itu, beraneka ragamnya

\footnotetext{
${ }^{12}$ Tim Visi Yustisia. 2015. Panduan Resmi Hak Cipta Dari Mendaftar, Melindungi, hingga Menyelesaikan Sengketa. Jakarta: Visimedia, h. 20.
} 
budaya yang ada di Indonesia tersebut sangat membutuhkan satu upaya perlindungan, terutama perlindungan hokum di dalamnyasebagai sebuah karya intelektual. Langkah-langkah semacam ini perlu dilakukan sebagai satu upaya yang dapat dilakukan guna menciptakan satu bentuk kepastian hukum. ${ }^{13}$

Sebagai suatu karya seni tradisional yang telah berlangsung secara turun temurun, maka perlindungan Hak Cipta atas karya tradisional suatu daerah akan dipegang oleh negara sebagaimana diatur dalam Pasa1 10 ayat 2 UUHC, yaitu:

"Negara memegang Hak Cipta atas folklore dan hasil kebudayaan rakyat yang menjadi milik bersama, seperti cerita, hikayat, dongeng, legenda, babad, lagu, kerajinan tangan, koreografi, tarian, kaligrafi, dan karya seni lainnya".

Secara etimologis, Ekspresi Budaya Tradisional berakar dalam tiga kata, tradisi, budaya dan ekspresi.Untuk "ekspresi", itu berarti untuk mengungkapkan atau tujuan yang jelas, ide atau perasaan.Budaya dalam bahasa Inggris sesuai dengan "budaya" di Indonesia. ${ }^{14} \mathrm{Hal}$ ini berakar pada bahasa Sansekerta "budhayah" yang berarti pikiran

\footnotetext{
${ }^{13}$ Dyah Permata Budi Asri, 2016, Implementasi Pasal 38 ayat (1) Undang-Undang Nomor 28 Tahun 2014 terhadap Ekspresi Budaya Tradisional di Kabupaten Sleman, Yogyakarta: Jurnal Hukum Ius Quia Iustum Fakultas Hukum Universitas Islam Indonesia, h. 616

${ }^{14}$ Koentjoroningrat, Pengantar Ilmu Antropologi, Rineka Cipta, Jakarta, 2009, hlm..69
}

atau intelektual. ${ }^{15}$ Secara umum, budaya dapat didefinisikan sebagai sesuatu yang dihasilkan oleh pikiran manusia dan intelek untuk mengembangkan dan mempertahankan hidup mereka di lingkungan mereka.ekspresi budaya tradisional adalah bagian dari kehidupan budaya masyarakat sebagai pemilik. ekspresi budaya tradisional sudah mengandung beberapa nilai seperti ekonomi, spiritualitas dan komunalitas. Semua nilainilai ini dihormati oleh masyarakat tradisional.Oleh karena itu, ekspresi budaya tradisional dapatmewakili identitas masyarakat adat di daerah tertentu. ${ }^{16}$

Hak Cipta adalah hak eksklusif pencipta yang timbul secara otomatis berdasarkan prinsip deklaratif setelah suatu ciptaan diwujudkan dalam bentuk nyata tanpa mengurangi pembatasan sesuai dengan ketentuan peraturan perundangundangan. ${ }^{17}$ Adanya hubungan yang erat antara perlindungan hak kekayaan intelektual (HKI) dengan peningkatan pertumbuhan ekonomi domestik di sebuah Negara sudah tidak dapat disangkal lagi. Pada Negara maju, misalnya mendapatkan keuntungan ekonomi dalam jumlah yang besar dari

\footnotetext{
${ }^{15}$ Deddy Mulyana, Komunikasi Antar Budaya : Paduan Berkomunikasi Dengan Orang-Orang Berbeda Budaya, Remaja Rosdakarya, Bandung, 2006, hlm..59

${ }^{16}$ Dominikus Rato, Pengantar Hukum Adat, LaksBang Pressindo, Surabaya, 2009, hlm.101

${ }_{17}$ Pasal 1 ayat 1 Undang-Undang Nomor 28 Tahun 2014 tentang Hak Cipta
} 
produk - produk HKI. ${ }^{18}$ Dalam rangka mewujudkan hak eklusif tersebut manusia berusaha menjaga dengan cara mendaftarkan kelembaga karya cipta, namun dalam konteks ini penciptaan karya manusia menggunakan usaha dan pikiran sendiri dalam proses pembuatannya untuk menunjukkan keasliannya dan ciri khas yang berbeda dalam setiap karya seni adapaun karya seni tersebut adalah lagu.Oleh karena itu untuk menghindari adanya unsur plagiasi. Muncullah sebuah undang-undang yang secara khusus untuk melindungi pemilik hak cipta baik yang terdaftar maupun yang belum terdaftar, undang-undang hak cipta ini lahir untuk memberikan kepastian hukum kepada para seniman atau seorang yang secara undangundang dijamin hak eklusifnya terhadap ciptaannya. ${ }^{19}$

Pengetahuan tradisional juga dapat berhubungan dengan bidang yang sangat penting bagi kehidupan, seperti pertanian, perikanan, kesehatan, hortikultura, dan kehutanan. Sebuah ide serupa diungkapkan oleh UNESCO (United Nations Educational, Scientific and Cultural Organization) melalui konvensi yang bertujuan untuk melindungi ekspresi budaya tradisional.konvensi ini

18 Utomo Suryo Tomi, 2010, Hak Kekayaan Intelektual di Era Global, Graha Ilmu, Yogyakarta, h. 41

${ }^{19}$ Dendi Martha Rahardja, 2015, Perlindungan Hukum Terhadap Pencipta Lagu Yang Belum Di Daftarkan Ke Drektorat Jendral Hak Kekayaan Intelektual (Analisis Pasal 40 Ayat 3 No. 28 Tahun 2014 Tentang Hak Cipta), Malang: Fakultas Hukum Universitas Brawijaya, h. 4 disebut sebagai Konvensi tentang Perlindungan Warisan Budaya. Konvensi ini berbicara tentang ekspresi, pengetahuan dan keterampilan yang dimiliki oleh masyarakat, kelompok dan / atau dalam beberapa kasus, individu, dan diklaim sebagai warisan budaya mereka. "Warisan budaya tak berwujud mungkin termasuk praktek, representasi, ekspresi, pengetahuan, dan keterampilan - serta alat-alat, benda, artefak dan ruang-ruang budaya - bahwa komunitas, kelompok dan / atau dalam beberapa kasus, individu, sebagai warisan budaya mereka.

Menurut WIPO, ekspresi budaya tradisional (atau ekspresi dari cerita rakyat) mungkin termasuk musik, seni, desain, nama, tanda, simbol, penampilan, arsitektur, kerajinan dan cerita. WIPO mendefinisikan pengetahuan tradisional sebagai kategori yang berisi ekspresi orang seperti musik, tari, lagu, kerajinan, desain, narasi, dan karya seni.Konvensi dan WIPO telah menggunakan definisi ini untuk mewakili karakteristik budaya yang terdiri dari benda-benda budaya sakral Objek dapat dimasukkan ke dalam ekspresi budaya tradisional mereka adalah ${ }^{20}$ (a) Dapat tertanam dan ditransfer melalui generasi; (b) dapat berkembang secara dinamis; dan (c) dapat dikelola sesuai dengan identitas masyarakat.

\footnotetext{
${ }^{20}$ M.Zulfa Aulia.2006, Perlindungan Hak Kekayaan Intelektual atas Pengetahuan Tradisional. Jakarta:FH UI,hlm.68
} 
Henry Merryman juga menyatakan bahwa perlindungan ekspresi budaya tradisional akan difokuskan pada menjaga bentuk asli dari ekspresi budaya tradisional untuk formulir ini masih mungkin memiliki kualitas khas sebagai sumber daya yang tak tergantikan. Penggunaan metode ini adalah untuk memahami konsep ekspresi budaya tradisional sebagai warisan budaya nasional karena warisan adalah manifestasi nasionalisme, kekayaan budaya bangsa di mana masyarakat dan pemerintah memberikan kontribusi besar untuk menjaga nilainilai dalam ekspresi budaya tradisional. Maria Aurora $\mathrm{Fe}$ Candelaria telah menegaskan bahwa bangsa ini sangat diperlukan untuk bertindak sebagai pendukung kedaulatan dan kepemilikan ekspresi budaya tradisional untuk: ${ }^{21}$ (a) Properti ekspresi budaya tradisional merupakan ekspresi dari sebuah peradaban yang pernah ada atau tumbuh di negeri sehingga warga negara memiliki hak untuk tetap sebagai kebanggaan nasional yang kuat;

(b) Retensi kedaulatan nasional diperlukan untuk melindungi ekspresi budaya tradisional dalam kualitas yang tepat, termasuk nilainilai ekonomi yang dapat digunakan oleh warga.

Perjuangan Indonesia sebagai salah satu negara berkembang untuk adanya

\footnotetext{
${ }^{21}$ Maria Aurora Fe Candelaria, The Angkor Sites of Cambodia: The Conflicting Values of Sustainable Tourism and State Sovereignty, 31 BROOK. J. INT'L L. 253, 2005
}

perlindungan hukum terus diselenggarakan untuk merumuskan sistem perlindungan yang tepat bagi Ekspresi Budaya Tradisional tersebut. Salah satunya dengan membuat RUU Pengetahuan Tradisional dan Ekspresi Budaya Tradisional (RUU PTEBT), yang hingga saat ini belum berhasil diundangkan sebagai undang-undang. Sementara keberadaan peraturan yang telah ada yaitu Undang-Undang Nomor 28 Tahun 2014 tentang Hak Cipta belum sepenuhnya dapat diberlakukan secara optimal, karena belum adanya peraturan pelaksanaannya hingga saat ini. $^{22}$

Terhadap Ekspresi Budaya Tradisional tersebut negara diberikan kewajiban yang dimuat dalam Pasal 38 ayat (2), yaitu kewajiban negara terhadap pemeliharaan dan pengelolaan budaya tradisional. Secara lengkap yang disampaikan dalam pasal tersebut adalah "Negara wajib menginventarisasi, menjaga, memelihara Ekspresi Budaya Tradisional sebagaimana dimaksud pada ayat (1)". ${ }^{23}$

Adanya kewajiban negara terhadap segala bentuk Ekspresi Budaya Tradisional dalam Undang-undang Hak Cipta Nomor 28 Tahun 2014 sudah disebutkan secara

${ }^{22}$ Dyah Permata Budi Asri, 2018, Perlindungan Hukum Preventif Terhadap Ekspresi Budaya Tradisional di Daerah Istimewa Yogyakarta Berdasarkan Undang-Undang Nomor 28 Tahun 2014 tentang Hak Cipta, Yogyakarta: Fakultas Hukum Janabadra, h. 14

${ }^{23}$ Pasal 38 ayat (1) berbunyi sebagai berikut : "Hak Cipta atas ekspresi budaya tradisional dipegang oleh Negara". 
eksplisit. Negara sebagai pihak pemilik budaya tradisional (dalam hal ini pemerintah daerah setempat) memiliki kewajiban dalam rangka pemeliharaan dan pengelolaan budaya tersebut, antara lain kewajiban untuk melakukan inventarisasi budaya, menjaga dan memelihara budaya dari segala bentuk pelanggaran maupun pemanfaatan budaya tradisional tanpa hak yang sah. Hanya saja ketentuan yang ditegaskan dalam undangundang tersebut sampai dengan saat ini belum bisa dilaksanakan karena berbagai kendala, antara lain peraturan teknis pelaksananya dan juga karena faktor sumber daya manusianya. 24 Peraturan teknis pelaksananya seperti belum adanya Peraturan Pemerintah yang mengatur mengenai ekspresi budaya tradisional yang dipegang oleh Negara serta RUU Pengetahuan Tradisional dan Ekspresi Budaya Tradisional yang masih dalam pembahasan sehingga belum dapat disahkan menjadi UndangUndang yang menjadi dasar hukum yang mengikat. Faktor manusia diantarnya adalah sikap masyarakat yang terkesan tidak peduli terhadap pentingnya mengenal keberagaman budayanya sendiri seperti lagu daerah.

Konsep perlindungan hukum terhadap Ekspresi Budaya Tradisional berbeda seperti halnya perlindungan hukum terhadap obyek hak cipta lainnya seperti yang terdapat dalam Undang-undang Nomor 2018 Tahun 2014

\footnotetext{
${ }^{24}$ Lihat Pasal 38 ayat (4) Undang-Undang Nomor 28 Tahun 2014 tentang Hak Cipta
}

Tentang Hak Cipta. Pencatatan Hak Cipta sebagaimana yang ada dalam Undangundang tersebut mengharuskan dilakukan dengan pencantuman nama pencipta, sebagai pihak yang akan diberikan perlindungan hukumnya, sekalipun prinsip pencatatan tersebut bukanmerupakan suatu kewajiban. Namun jika berbicara mengenai ekspresi budaya tradisional yang merupakan bagian dari karya cipta, jika pencatatannya dilakukan maka yang menjadi pemegang hak cipta ada Negara sesuai yang diamanatkan dalam Pasal 38 ayat (2) Undang-undang Hak Cipta. Hal ini disebabkan karena pencipta terhadap ekspresi kebudayaan tradisional tidak lagi diketahui. Kewajiban yang harus dilakukan oleh negara sebagai pemegang Hak Cipta atas ekspresi kebudayaan tradisioanal adalah melakukan inventarisasi dan dokumentasi kebudayaan tersebut. ${ }^{25}$

Adanya ketentuan kewajiban Negara terhadap ekspresi budaya tradisional sesuai yang ada pada Pasal 38 Undang-undang Nomor 28 Tahun 2014, menunjukan pentingnya perlindungan terhadap ekspresi budaya tradisional, yang merupakan aset yang sangat berharga dari pemerintah. Terkait banyaknya pelanggaran pemanfaatan dan klaim kebudayaan yang terjadi beberapa waktu yang lalu oleh Malaysia, membuktikan bahwa ancaman terhadap pelanggaran pemanfaatan maupun klaim kebudayaan

\footnotetext{
${ }^{25}$ Dyah Permata Budi Asri, h. 15
} 
sangat berpotensi terjadi terlebih Indonesia sebagai negara yang memiliki beragam jenis kebudayaan.

Ekspresi Budaya Tradisional menurut penjelasan Pasal 38 ayat (1) Undang-undang No 28 Tahun 2014 adalah yang mencakup salah satu atau kombinasi bentuk ekspresi sebagai berikut: (1) Verbal tekstual, baik lisan maupun tulisan, yang berbentuk prosa maupun puisi, dalam berbagai tema dan kandungan isi pesan, yang berbentuk karya sastra ataupun narasi informatif; (2) Musik, mencakup antara lain, vokal, instrumental, atau kombinasinya; (3) Gerak, mencakup antara lain, tarian; (4) Teater, mencakup antara lain, pertunjukan wayang dan sandiwara rakyat; (5) Seni rupa, baik bentuk dua dimensi maupun tiga dimensi yang terbuat dari, berbagai macam bahan seperti kulit, kayu, bambu, logam, batu, keramik, kertas, tekstil, dan lain-lain atau kombinasinya; dan (6) Upacara adat.

Negara sebagai pemegang Hak Cipta Ekspresi Budaya Tradisional memperoleh Hak Eksklusif atas Karya Cipta tersebut. Hak-hak eksklusif yang diatur dalam Undang-undang Hak Cipta adalah hak untuk menerbitkan, menerjemahkan, menggandakan, mentransformasi, mengadaptasi, mempertunjukkan dan mengumumkan.

Negara sebagai otoritas tertinggi, dan pemerintah daerah sebagai representasi negara dalam perlindungan dan pengaturan
Ekspresi Budaya Tradisional dapat mencegah adanya monopoli atau komersialisasi serta tindakan yang merusak atau pemanfaatan komersialisasi oleh pihak asing tanpa seizin negara sebagaipemegang Hak Cipta. Hanya saja sampai saat ini belum ada Peraturan Pemerintah yang mengatur lebih lanjut tentang hak cipta yang dipegang oleh Negara. $^{26}$

\section{Penutup}

\section{Simpulan}

Lagu daerah yang tidak diketahui Penciptanya dipegang oleh Negara sehingga peran negara sangat penting dalam perlindungan hukum lagu daerah. Lagu daerah yang tidak diketahui penciptanya diatur dalam Pasal 38 Undang-Undang Nomor 28 Tahun 2014 tentang Hak Cipta namun belum ada aturan turunan seperti Peraturan Pemerintah yang mengatur secara khusus mengenai pengaturan lagu daerah sebagaimana dimaksud dalam Pasal 38 ayat (4) Undang-Undang Nomor 28 Tahun 2014 tentang Hak Cipta. RUU Pengetahuan Tradisional dan Ekspresi Budaya Tradisional masih dalam pembahasan sehingga tidak dapat dijadikan sebagai sumber hukum dalam perlindungan lagu daerah yang tidak diketahui penciptanya. RUU Pengetahuan Tradisional dan Ekspresi Budaya Tradisional (RUU PTEBT) diharapkan segera disahkan

\footnotetext{
${ }^{26}$ Reh Bungana BeruPerangin-angin,. 2017. Prosiding Seminar Nasional Tahunan Fakultas Ilmu Sosial Universitas Negeri Medan. e-ISSN: $2549-5976$ pISSN: 2549-435X, h. 65
} 
menjadi Undang-Undang sehingga dapat menjadi dasar hukum perlindungan lagu daerah.

\section{Saran}

Perlu adanya aturan yang secara khusus yakni Undang-Undang mengatur mengenai Pengetahuan Tradisional dan Ekspresi Budaya Tradisional sehingga tidak lagi diatur dalam Undang-Undang Hak Cipta yang hanya sedikit membahas Pengetahuan Tradisional dan Ekspresi Budaya Tradisional. Setidaknya ketentuan lebih lanjut mengenai Pengetahuan Tradisional dan Ekspresi Budaya Tradisional yang terdapat dalam Pasal 38 ayat (4) Undang-Undang Nomor 28 Tahun 2014 tentang Hak Cipta segera dibuat dan disahkan karena sampai saat ini tidak ada.

\section{Daftar Pustaka}

\section{Buku dan Jurnal}

Deddy Mulyana, 2006, Komunikasi Antar Budaya : Paduan Berkomunikasi Dengan Orang-Orang Berbeda Budaya, Bandung :Remaja Rosdakarya

Dendi Martha Rahardja, 2015, Perlindungan Hukum Terhadap Pencipta Lagu Yang Belum Di Daftarkan Ke Drektorat Jendral Hak Kekayaan Intelektual (Analisis Pasal 40 Ayat 3 No. 28 Tahun 2014 Tentang Hak Cipta), Malang: Fakultas Hukum Universitas Brawijaya

Dominikus Rato, 2009, Pengantar Hukum Adat, Surabaya : LaksBang Pressindo

Dyah Permata Budi Asri, 2016, Implementasi Pasal 38 ayat (1) Undang-Undang Nomor 28 Tahun 2014 terhadap Ekspresi Budaya Tradisional di
Kabupaten Sleman, Yogyakarta: Jurnal Hukum Ius Quia Iustum Fakultas Hukum Universitas Islam Indonesia

Johnny Ibrahim, 2006, Teori dan Metodologi Penelitian Hukum Normatif, Malang: Bayumedia Publishing

Koentjoroningrat, 2009, Pengantar Ilmu Antropologi, Jakarta: Rineka Cipta

M.Zulfa Aulia.2006, Perlindungan Hak Kekayaan Intelektual atas Pengetahuan Tradisional. Jakarta:FH UI

Maria Aurora Fe Candelaria, 2005, The Angkor Sites of Cambodia: The Conflicting Values of Sustainable Tourism and State Sovereignty, 31 BROOK. J. INT'L L.

Muhamad Djumhana, 2003, Hak Milik Intelektual (Sejarah, Teori dan Prakteknya di Indonesia), Bandung: PT Citra Aditya Bakti

Reh Bungana Beru Perangin-angin,. 2017. Prosiding Seminar Nasional Tahunan Fakultas Ilmu Sosial Universitas Negeri Medan. e-ISSN: 2549-5976 pISSN: 2549-435X

Tim Visi Yustisia. 2015. Panduan Resmi Hak Cipta Dari Mendaftar, Melindungi, hingga Menyelesaikan Sengketa. Jakarta: Visimedia

Utomo Suryo Tomi, 2010, Hak Kekayaan Intelektual di Era Global, Graha Ilmu, Yogyakarta

Wahyu Sasongko. 2012. Indikasi Geografis Studi Tentang Kesiapan Indonesia Memberikan Perlindungan Hukum Terhadap Produk Nasional. Bandar Lampung: Universitas Lampung 


\section{Peraturan Perundang-Undangan}

Undang-undang Nomor 28 Tahun 2014

tentang Hak Cipta

\section{Internet}

Achmad Rafiq, 2014 Lagu Daerah Antarkan

Ten 2 Five ke Luar Negeri, https://www.tribunnews.com/se leb/2014/12/05/lagu-daerah-antarkanten-2-five-ke-luar-negeri

WIPO,https://www.wipo.int/edocs/mdocs/sm e/en/wipo_smes_ge_10/wipo_smes_ge 10_ref theme11_02.pdf 